\title{
Competitive Adsorption of Heavy Metals from Water using Pumice Supported Nano Scale Zero-Valent Iron
}

\author{
B.I. HARMAN ${ }^{a, *}$, N.S. IBRAHIM ${ }^{b}$ \\ ${ }^{a}$ Technical Science Vocational School, Suleyman Demirel University, 32260 Isparta, Turkey \\ ${ }^{b}$ Department of Environmental Eng., Suleyman Demirel University, 32260 Isparta, Turkey
}

\begin{abstract}
The objectives of this study are to synthesize pumice supported nanoscale zero-valent iron (P-nZVI), to characterize it and to test its removal capacity of heavy metals. Characteristics of P-nZVI are investigated using SEM-EDX, BET and XRF. The characterization results show that nZVI particles were effectively attached and well dispersed on the surface of pumice. To identify the effectiveness of pumice modification, the RP and P-nZVI were used for adsorption of $\mathrm{Ni}(\mathrm{II}), \mathrm{Zn}(\mathrm{II})$ and $\mathrm{Cd}(\mathrm{II})$. Pumice coated with nZVI shows high efficiency in the removal of $\mathrm{Ni}(\mathrm{II}), \mathrm{Zn}(\mathrm{II})$ and $\mathrm{Cd}(\mathrm{II})$.
\end{abstract}

DOI: 10.12693/APhysPolA.134.171

PACS/topics: nZVI, pumice, characterization, material modification

\section{Introduction}

Water pollution by heavy metals has become one of the most difficult problems in the present day. The toxic effects of heavy metals, such as $\mathrm{Ni}(\mathrm{II}), \mathrm{Zn}(\mathrm{II})$ and $\mathrm{Cd}(\mathrm{II})$, on human health have been investigated extensively [1]. Based on the foregoing, the heavy metals should be removed from the wastewater and their concentration must not exceed the permitted limits. Adsorption is one of the most common processes in the removal of heavy metals, due to its favorable features $[2,3]$.

Pumice is a porous volcanic rock which has a skeleton structure formed during the volcanic explosions [4]. Pumice can be processed easily and used effectively as low-cost adsorbent of heavy metals [5]. In particular, its adsorption capacity will increase after modification of pumice to provide more reaction sites for heavy metals $[6,7]$.

Nano zero-valent iron (nZVI) has recently been shown to have high affinity to various types of metallic ions. Application of ZVI in the form of nano-particles has become one of the most promising and effective technologies to improve its properties, due to small particle size, large surface area and high removal efficiency $[8,9]$. However, nZVI is easily oxidized to iron oxides under aerobic conditions. Therefore, its application is primarily restricted to anaerobic conditions [10].

nZVI is usually agglomerated because of its high surface energy and intrinsic magnetic interactions. To overcome this problem pumice with a porous structure has been used as a mechanical support, to promote the stability of nZVI particles against oxidation and agglomeration. However, only a few studies have focused on using pumice as the support material for nZVI.

*corresponding author; e-mail: ilkerharman@sdu.edu.tr
The aim of this work is (1) to obtain a material with a high adsorption ability by merging nZVI particles, (2) to characterize the raw pumice (RP) and P-nZVI by SEMEDX, BET and XRF and (3) to investigate the simultaneous removal of $\mathrm{Ni}(\mathrm{II}), \mathrm{Zn}(\mathrm{II})$ and $\mathrm{Cd}(\mathrm{II})$ from model solution by using RP and pumice-supported nZVI (PnZVI). To our knowledge, pumice-supported nZVI was not previously investigated for removal of $\mathrm{Ni}(\mathrm{II}), \mathrm{Zn}$ (II) and $\mathrm{Cd}(\mathrm{II})$ from water.

\section{Materials and equipment}

\subsection{Materials}

Pumice particles were provided by pumice research and application center at Suleyman Demirel University, Isparta, Turkey. Chemicals including $\left(\mathrm{FeCl}_{3}\right),\left(\mathrm{NaBH}_{4}\right)$, $\left(\mathrm{NiSO}_{4} \cdot 6 \mathrm{H}_{2} \mathrm{O}\right)$ and $\left(\mathrm{ZnSO}_{4} \cdot 7 \mathrm{H}_{2} \mathrm{O}\right)$ were purchased from Merck, while $\left(\mathrm{CdSO}_{4}\right)$ and ethanol were supplied from Acros Organics and J.T. Baker, respectively. The concentrations of $\mathrm{Ni}(\mathrm{II}), \mathrm{Zn}(\mathrm{II})$ and $\mathrm{Cd}(\mathrm{II})$ were measured by inductively coupled plasma mass spectrometry (ICPMS, NexIONTM 300X) and the single metal standards used for $\mathrm{Ni}(\mathrm{II}), \mathrm{Zn}(\mathrm{II})$ and $\mathrm{Cd}(\mathrm{II})$ analysis were supplied from Perkin Elmer.

\subsection{Preparation of modified pumice (P-nZVI)}

Initially pumice particles (less than 63-micron fraction) were pretreated with $1 \mathrm{M} \mathrm{HCl}$ to enhance its porosity and to remove the surface impurities. The nano scale zero valent iron was synthesized by using conventional liquid-phase method, the reduction of $\mathrm{FeCl}_{3}$ was carried out using $\mathrm{NaBH}_{4}$ as reducing agent [11, 12]. Deposition on the pumice was carried out by employing the method reported by Liu et al. in [6].

Pumice $(3.36 \mathrm{~g})$ was added into a neck flask. Iron solution was prepared by dissolving $\mathrm{FeCl}_{3}$ in the water/ethanol mixture. The $\mathrm{FeCl}_{3}$ solution was added into the flask and left for mixing for 1 hour. After the end of mixing time, freshly prepared $\mathrm{NaBH}_{4}$ solution was added to the mixture. After addition of $\mathrm{NaBH}_{4}$ solution the 
mixture was mixed for 1 hour. The solid-liquid phase separation was done by centrifugation. The precipitated P-nZVI was dried at $65^{\circ} \mathrm{C}$ over the night. All experiments were performed in nitrogen atmosphere to prevent iron oxidation.

\section{Results and discussion}

\section{1. $S E M-E D X$}

The SEM image of raw pumice before modification with nZVI is shown in Fig. 1a. It reveals that the raw pumice had porous structure. Figure 1b shows SEM image of the P-nZVI. The presence of nZVI on the surface of pumice indicates that nZVI is immobilized and distributed heterogeneously on the surface, suggesting an effective coating process. Nano zero-valent iron particles were rough with a round shape. The coarse conformation of the nZVI particles could increase the number of active sites that take part in the adsorption process.

nZVI particles $(70-80 \mathrm{~nm})$ were positioned on the surface of pumice without aggregation and thus increase the surface area of the pumice. This is in agreement with the results obtained by BET analysis. After adsorption, the surface of P-nZVI became rough (Fig. 1c) due to the formation of deposits on the P-nZVI surface.

Energy dispersive X-ray (EDX) analysis was recorded to indicate the surface elemental content of RP and $\mathrm{P}$-nZVI before and after the adsorption of $\mathrm{Ni}(\mathrm{II}), \mathrm{Zn}(\mathrm{II})$ and Cd(II) ions. The EDX results are shown in Table I. The raw pumice was rich in silica [6], where the weight proportion of silica as high as $31.6 \%$ and the iron content of about 2.8 wt. $\%$ were observed.

After the modification of RP with nZVI the weight percentage of Si decreased to 23.05 wt.\%. However, the percentage of Fe increased to 14.34 wt.\%. The increase of iron content originates from nZVI particles. EDX analysis of P-nZVI following the uptake of $\mathrm{Ni}(\mathrm{II}), \mathrm{Zn}$ (II) and $\mathrm{Cd}(\mathrm{II})$ ions indicates that the weight percentage of $\mathrm{Ni}(\mathrm{II})$, $\mathrm{Zn}(\mathrm{II})$ and $\mathrm{Cd}(\mathrm{II})$ increased to $2.2 \%, 1.98 \%$ and $1.71 \%$, respectively, thereby, confirming the adsorption of the $\mathrm{Ni}(\mathrm{II}), \mathrm{Zn}(\mathrm{II})$ and $\mathrm{Cd}(\mathrm{II})$ ions on the P-nZVI surface.
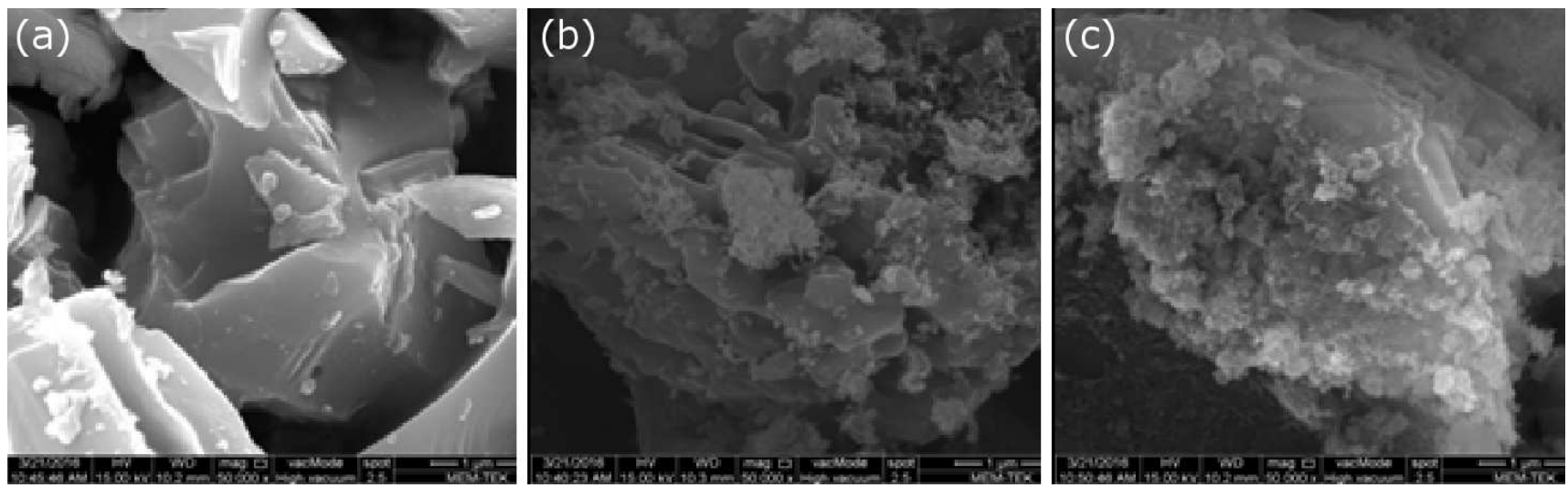

Fig. 1. SEM images of (a) raw pumice, (b) nZVI coated pumice before adsorption, and (c) nZVI coated pumice after adsorption.

Elemental composition (wt.\%) of raw pumice and P-nZVI obtained by EDX analysis

TABLE I

\begin{tabular}{l|c|c|c|c|c|c|c|c|c|c}
\hline \hline \multicolumn{1}{c|}{ Elements } & $\mathrm{O}$ & $\mathrm{Si}$ & $\mathrm{Al}$ & $\mathrm{K}$ & $\mathrm{C}$ & $\mathrm{Fe}$ & $\mathrm{Na}$ & $\mathrm{Ni}$ & $\mathrm{Zn}$ & $\mathrm{Cd}$ \\
\hline $\mathrm{RP}$ & 38.56 & 31.6 & 10.34 & 5.25 & 2.52 & 2.8 & 4.3 & 0.47 & 0.89 & 0.31 \\
\hline P-nZVI before adsorption & 39.34 & 23.05 & 7.25 & 3.47 & 1.81 & 14.34 & 8.51 & 0.14 & 0.45 & - \\
\hline P-nZVI after adsorption & 31.37 & 21.76 & 7.05 & 3.46 & 8.07 & 16.26 & 3.79 & 2.2 & 1.98 & 1.71
\end{tabular}

\section{2. $B E T$}

The specific surface area of P-nZVI was measured by BET-N $\mathrm{N}_{2}$ surface area analyzer. When pumice was loaded with nZVI particles (P-nZVI), the mean specific surface area of 8.4 and $6.3 \mathrm{~m}^{2} / \mathrm{g}$ was obtained by Langmuir and BET adsorption isotherm, respectively. Which was 4 and 3 times larger than those of the raw pumice 2 and $2.7 \mathrm{~m}^{2} / \mathrm{g}$ [13]. Modification process has led to an increase in the surface area of pumice and reduced the aggregation of nZVI. The mechanical strength might be increased with the decrease of aggregation.

\section{3. $X R F$}

The X-ray fluorescence (XRF) analyses of P-nZVI were conducted. RP sample was predominantly rich in $\mathrm{SiO}_{2}(53 \%$ by weight $)$. The $\mathrm{Fe}_{2} \mathrm{O}_{3}$ content was about 3.77 wt.\% [13]. For the P-nZVI, the XRF analysis shows that the amount of $\mathrm{Fe}_{2} \mathrm{O}_{3}$ was $14.78 \%$ by weight and the amount of $\mathrm{SiO}_{2}$ was $37.42 \%$. Usage of sodium borohydride during the synthesis of nZVI has led to actual increase in the $\mathrm{Na}_{2} \mathrm{O}$ percentage $(18 \%)$, as well. The results indicate that the modification of pumice with nZVI was successfully achieved. 


\subsection{Adsorption tests}

The simultaneous removal of the three contaminants (concentrations of heavy metals: $10 \mathrm{mg} / \mathrm{l}$; adsorption time: 20 minutes; $150 \mathrm{rpm}$; temperature: $20 \pm 5^{\circ} \mathrm{C}$ ) by $\mathrm{RP}$ and P-nZVI were studied by bottle point adsorption method and the results are shown in Fig. 2. From Fig. 2, the $\mathrm{Ce} / \mathrm{Co}$ values of $\mathrm{Ni}(\mathrm{II}), \mathrm{Zn}(\mathrm{II})$ and $\mathrm{Cd}(\mathrm{II})$ adsorption by $\mathrm{RP}$ were decreased to $0.96,0.84$ and 0.88 , respectively, when the adsorbent dose increased to $2000 \mathrm{mg} / \mathrm{l}$. The low adsorption capability of raw pumice is due to its small surface area. Therefore, pumice dose did not enhanced the removal efficiency.

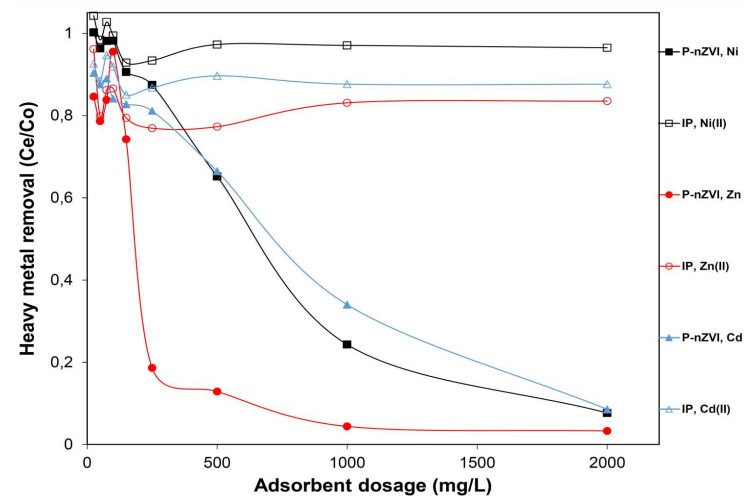

Fig. 2. The simultaneous removal of the three contaminants (concentrations of heavy metals: $10 \mathrm{mg} / \mathrm{l}$; adsorption time: 20 minutes; $150 \mathrm{rpm}$; temperature: $\left.20 \pm 5{ }^{\circ} \mathrm{C}\right)$.

However very high removal rates were obtained with P-nZVI. The results of adsorption of $\mathrm{Ni}(\mathrm{II}), \mathrm{Zn}(\mathrm{II})$ and Cd(II) by P-nZVI show that the removal of each of the heavy metals is unaffected by the presence of the other metals, the $\mathrm{Ce} / \mathrm{Co}$ values of $\mathrm{Ni}(\mathrm{II}), \mathrm{Zn}(\mathrm{II})$ and $\mathrm{Cd}(\mathrm{II})$ dropped to $0.08,0.03$, and 0.09 , respectively. From the result it can be concluded that the modification of pumice with nZVI is an important step to obtain a highly effective material for adsorption of heavy metals. The removal rate of P-nZVI increases with the increase of adsorbent dose. This can be explained as follows, when the P-nZVI dose increases, the number of available active sites able to adsorb metal ions will increase $[7,14]$. The removal efficiency of $\mathrm{Zn}$ (II) is smaller compared to those of $\mathrm{Ni}(\mathrm{II})$ and $\mathrm{Cd}(\mathrm{II})$, which is confirmed by the results of other research $[15,16]$. P-nZVI is obviously advantageous for the simultaneous heavy metal removal.

\section{Conclusions}

We conclude with the following highlights;

- Pumice particles were successfully modified with nZVI. This finding has been confirmed by SEMEDX and XRF characterization methods,

- It was observed that nZVI particles are distributed heterogeneously on the surface of pumice,

- Surface area of pumice was increased by modification,
- nZVI coated pumice shows high efficiency in the removal of $\mathrm{Ni}(\mathrm{II}), \mathrm{Zn}(\mathrm{II})$ and $\mathrm{Cd}(\mathrm{II})$,

- After the modification of RP, iron content of the samples was increased.

- After adsorption tests, samples were analyzed with EDX. It was observed that weight percentage of $\mathrm{Ni}(\mathrm{II}), \mathrm{Zn}(\mathrm{II})$ and $\mathrm{Cd}(\mathrm{II})$ increased compared with raw pumice. This result, confirms the adsorption of the $\mathrm{Ni}(\mathrm{II}), \mathrm{Zn}(\mathrm{II})$ and $\mathrm{Cd}(\mathrm{II})$ ions on the P-nZVI surface,

- The removal rate of P-nZVI increases with the increase of the adsorbent dose. The removal efficiency of $\mathrm{Zn}(\mathrm{II})$ is smaller compared to those of $\mathrm{Ni}(\mathrm{II})$ and $\mathrm{Cd}(\mathrm{II})$,

- From the results it can be concluded that the modification of pumice with nZVI is an important step to obtain a highly effective material for adsorption of heavy metals.

\section{References}

[1] I. Hsanullah, A. Abbas, M. Adnan, Al-Amer, T. Laoui, M.J. Al-Marri, M.S. Nasser, M. Khraisheh, M.A. Atieh, Sep. Purif. Technol. 157, 141 (2016).

[2] J. Saiz, E. Bringas, I. Ortiz, J. Chem. Technol. Biotechnol. 89, 909 (2014).

[3] P. Ruseka, Z. Hubicki, G. Wójcik, A. Debczak, Acta Phys. Pol. A 116, 407 (2009).

[4] I. Akkurt, H. Akyildirim, B. Mavi, Ş. Kilinçarslan, C. Başyiğit, Acta Phys. Pol. A 121144 (2012).

[5] P. Catalfamo, I. Arrigo, P. Primerano, F. Corigliano, J. Hazard. Mater. 134, 140 (2006).

[6] T. Liu, Z.L. Wang, X. Yan, B. Zhang, Chem. Eng. J. 245, 34 (2014).

[7] T. Liu, Z.L. Wang, Y. Sun, Chem. Eng. J. 263, 55 (2015).

[8] W. Zhang. J. Nanopart. Res. 5, 323 (2003).

[9] S.R. Kanel, J.M. Greneche, H. Choi, Environ. Sci. Technol. 40(6), 2045 (2006).

[10] J.T. Nurmi, P.G. Tratnyek, V. Sarathy, D.R. Baer, J.E. Amonette, K. Pecher, C. Wang, J.C. Linehan, D.W. Matson, R.L. Penn, M.D. Driessen, Environ. Sci. Technol. 39(5), 1221 (2005).

[11] C. Uzum, T. Shahwan, A.E. Erolu, K.R. Hallam, T.B. Scott, I. Lieberwirth, Appl. Clay Sci. 43, 172 (2009).

[12] C. Wang, W. Zhang, Environ. Sci. Technol. 31, 2154 (1997).

[13] B.I. Harman, M. Genisoglu, Adv. Mater. Sci. Eng. 2016, 4372136 (2016).

[14] B.A. Manning, J.R. Kiser, H. Kwon, S.R. Kanel, Environ. Sci. Technol. 41, 586 (2007).

[15] J. Dries, L. Bastiaens, D. Springael, L. Diels, S.N. Agathos, IAHS Special Publication. Wallingford, Oxforshire, UK 275, 447 (2002).

[16] S. Bilardi, P.S. Calabro, N. Moraci, Desalin. Water Treatm. 55(3), 767 (2015). 